\title{
Virus Infections in Pregnancy
}

Guest Editor

Uwe G. Liebert, Leipzig

28 figures and 32 tables, 1999 


\section{KARGER}

S. Karger

Medical and Scientific Publishers

Basel $\cdot$ Freiburg $\cdot$ Paris $\cdot$ London

New York $\cdot$ New Delhi $\cdot$ Bangkok

Singapore $\cdot$ Tokyo $\cdot$ Sydney
Drug Dosage

The authors and the publisher have exerted every effort to ensure that drug selection and dosage set forth in this text are in accord with current recommendations and practice at the time of publication. However, in view of ongoing research, changes in government regulations, and the constant flow of information relating to drug therapy and drug reactions, the reader is urged to check the package insert for each drug for any change in indications and dosage and for added warnings and precautions. This is particularly important when the recommended agent is a new and/or infrequently employed drug.
All rights reserved.

No part of this publication may be translated into other languages, reproduced or utilized in any form or by any means, electronic or mechanical, including photocopying, recording, microcopying, or by any information storage and retrieval system, without permission in writing from the publisher or, in the case of photocopying, direct payment of a specified fee to the Copyright Clearance Center (see 'General Information')

(C) Copyright 1999 by S. Karger AG,

P.O. Box, CH-4009 Basel (Switzerland)

Printed in Switzerland on acid-free paper by

Reinhardt Druck, Basel

ISBN 3-8055-6872-X 
145 Editorial

Viruses and Pregnancy

Liebert, U.G. (Leipzig)

149 Cytomegalovirus Infection in Pregnancy: A Still Complicated Diagnostic Problem

Lazzarotto, T.; Spezzacatena, P.; Pradelli, P.; Abate, D.A.; Gabrielli, L.; Varani, S.; Landini, M.P. (Bologna)

158 Should We Routinely Screen for Cytomegalovirus Antibody during Pregnancy?

Grangeot-Keros, L.; Simon, B.; Audibert, F.; Vial, M. (Clamart)

163 Rubella Virus Genome Diagnosis during Pregnancy and Mechanism of Congenital Rubella

Katow, S. (Tokyo)

170 Predictive Value of Serological Tests in Rubella Virus Infection during Pregnancy

Pustowoit, B.; Liebert, U.G. (Leipzig)

178 Parvovirus B19 Infection in Pregnancy

Eis-Hübinger, A.M.; Dieck, D.; Schild, R.; Hansmann, M.; Schneweis, K.E. (Bonn)

185 Herpes simplex Virus Infection in Pregnancy: Diagnosis and Significance Desselberger, U. (Cambridge)

191 Varicella-Zoster Virus Infections in Pregnancy Sauerbrei, A. (Jena)

197 Hepatitis B Maternal-Fetal Transmission in Southern Europe Papaevangelou, G.; Farmaki, G.; Kada, H. (Athens)

201 Human Immunodeficiency Virus and Hepatitis B Virus Infection in Pregnancy: Diagnostic Potential of Viral Genome Detection Berger, A.; Doerr, H.W. (Frankfurt am Main); Weber, B. (Frankfurt am Main/Junglinster)

208 A Prospective Study on Mother-to-Infant Transmission of Hepatitis C Virus Zanetti, A.R.; Tanzi, E.; Romanò, L.; Zuin, G. (Milan); Minola, E. (Bergamo); Vecchi, L. (Monza); Principi, N. (Milan)

213 Transmission of Cervical Cancer-Associated Human Papilloma Viruses from Mother to Child Cason, J.; Rice, P.; Best, J.M. (London)

219 Placental and Fetal Pathology in Intrauterine Viral Infections Horn, L.-C. (Leipzig); Röse, I. (Magdeburg)

226 Fetal Cells from Maternal Blood: Purpose, Biological Questions, Technical Challenges

Bohmer, R.M. (Boston, Mass.)

232 Author Index Vol. 41, No. 4-5, 1998

232 Subject Index Vol. 41, No. 4-5, 1998

\section{KARGER}

Fax+4161306 1234

E-Mail karger@karger.ch www.karger.com
(C) 1999 S. Karger AG, Basel

Access to full text and tables of contents, including tentative ones for forthcoming issues: www.karger.com/journals/int/int_bk.htm 